\title{
Experimental Study on the Negative Skin Friction of the Pile Group Induced by Rising and Lowering the Groundwater Level
}

\author{
Yu Zhang, ${ }^{1}$ Li-Pei Zhou $\mathbb{D}^{2,3}$ Ming-Yuan Wang ${ }^{20,}{ }^{2,3}$ Xuanming Ding, \\ and Chenglong Wang ${ }^{1}$ \\ ${ }^{1}$ College of Civil Engineering, Chongqing University, Chongqing 400045, China \\ ${ }^{2}$ Powerchina Huadong Engineering Corporation Limited, Hangzhou 310014, China \\ ${ }^{3}$ Zhejiang Engineering Research Center of Marine Geotechnical Investigation Technology and Equipment, \\ Hangzhou 310014, China
}

Correspondence should be addressed to Ming-Yuan Wang; wmy_90@163.com

Received 15 July 2021; Accepted 9 September 2021; Published 25 September 2021

Academic Editor: Qiang Tang

Copyright (c) $2021 \mathrm{Yu}$ Zhang et al. This is an open access article distributed under the Creative Commons Attribution License, which permits unrestricted use, distribution, and reproduction in any medium, provided the original work is properly cited.

\begin{abstract}
Negative skin friction (NSF) has been one of the important factors in the design of pile foundation; especially, the influence of water level on the pile negative skin friction should be paid attention. In this paper, a series of model tests were carried out to analyze the bearing characteristic of the pile group influenced by groundwater level. The pile axial force and negative skin friction, settlement, and soil pore pressure were investigated. The results showed that both the water level rising and lowering cycle could increase the axial force of the pile along the upper part of the pile, yet reducing it along the lower part of the pile; both the axial force and the negative skin friction of the pile presented a feature of time effect; the value of negative skin friction was positively correlated with that of the pile head load, and the neutral plane ranged from $0.57 \mathrm{~L}$ to $0.64 \mathrm{~L}$ as the water level changed; the soil featured settling in layers, and the change of pore water pressure was accordant with the water level changing regulation.
\end{abstract}

\section{Introduction}

Negative skin friction (NSF), regarded as an unfavorable load on the pile, develops where the settlement of the surrounding soil exceeds that of the pile, which may well induce force in the pile, thus resulting in ambiguous design in the pile bearing capacity and even some engineering failures like pile damage, uneven settlement of the structure, and foundation failure [1-3]. Negative skin friction mainly occurs in surface loading, withdrawal of water level, stillconsolidation soft layers, and the combination of those mentioned occasions [4].

At present, researchers have shown increased interest in pile design of pile-soil interaction [5-9]; however, it remains rough and ambiguous in reservoir areas due to limited awareness of NSF problems caused by water level changing periodically. Baihetan hydropower station, located in the lower reaches of the Jinsha River, stands as an important hydroelectric power station in China and offers electric power for the south-western area. Water level rises and lowers yearly for maintaining the reservoir running, which may well influence the safety of self-built houses by locals. To meet the requirements of migration and resettlement, highrising buildings were constructed in a high fill area, which requires strictness in deformation and bearing capacity of the pile foundation during the period of water level rising and lowering. Based on this, the effect of negative skin friction plays a significant role in the design of this case and consequently is worth further studying.

Awareness is growing that negative skin friction is worth more detailed studies other than being treated grossly in design codes. Sufficient works including field and model tests, numerical analysis, and theories have been carried out since the NSF concept was formally proposed by Terzaghi and Peck in the 1930s. Wong and Teh [10] proposed a simplified numerical method towards NSF on piles in layered soil deposit. Lee et al. [11] further clarified the NSF of piles in groups connected to a cap in 
soil slip. Kong et al. [12] and Hong et al. [13] conducted a series of model and field tests to investigate NSF effected by surcharge grade. Tan and Fellenius [14] proposed a new pile design method through evaluating various design codes.

Most previous studies are focused on surcharge and consolidation of soft layers, which is commonly acknowledged engineering problems in this area; however, the influence of water is yet to be paid enough attention and sufficient study. Only a few studies can be found on how negative skin friction factored down the behavior of piles in lowering water level. Lee and Chen [15] performed centrifuge model tests to study the influence of lowering of groundwater level on pile negative skin friction. Then, Fahmi et al. [16] studied land subsidence due to withdrawal of groundwater level by FE analysis. Furthermore, Fu [17] carried out centrifuge model tests considering cyclic water lifting. Al-Omari et al. [18-22] conducted a series of tests to evaluate the excess pore water pressure, the matric suction, the dynamic response and behavior of piles, the clay-pile adhesion, and the load transfer in piles in saturated and unsaturated soil.

The research work on NSF caused by water level is still lacking in attention and systematic study, especially the factor that the rising and lowering cycle of water level, which is encountered commonly in engineering sites, however, remains blank in specific mechanisms and principles on how the variation of groundwater level affects pile foundation.

In this paper, a series of model tests were conducted to study how the bearing characteristics of the pile group, especially the axial force and the negative skin friction, were influenced by groundwater level rising and lowering. The pore water pressure as well as settlement of pile and surrounding soil was also investigated. The results are beneficial to properly understand how piles behave in varying water level, which might help provide some guidance for the pile design in reservoir areas, and will lay out groundwork for future research in more systematic and specific analysis of pile bearing characteristics under varying water level condition.

\section{Materials and Methods}

2.1. Test Equipment. The geotechnical model test system was located in the Geotechnical Laboratory of Chongqing University. The dimension of the test chamber was $3.5 \mathrm{~m} \times 2 \mathrm{~m} \times 2.5 \mathrm{~m}$ (length $\times$ width $\times$ height $)$, which was large enough to reduce the effect of the edges. Along the chamber wall and chamber bottom, as shown in Figure 1, HDPE geomembrane was placed to avoid water leakage. A servo hydraulic actuator fixed on a steel frame beam was used for the pile head loading system. A force sensor and a displacement sensor were installed in the loading system, and the force and displacement of cap center could be obtained timely. Besides, each pile was topped with a vertical displacement gauge to record the pile head settlement. The model tests of $2 \times 2$ pile group with a pile cap were carried out.
The layout of the geometrical model and the arrangement of measure elements are illustrated in Figure 2. Layered settlement marks and vertical displacement gauges were set to measure the settlement of soil in layers as well as that on the surface. Pore pressure gauges were adopted for the purpose of describing the variation of pore pressure during the water injection and drainage.

2.2. Model Pile. Four cylindrical piles were prepared from PVC pipes of $1500 \mathrm{~mm}$ in length $(L)$ and $106 \mathrm{~mm}$ inner diameter $(D)$, and the distance was set as approximately $3 D$ for each pile. The $2 \times 2$ group piles with a pile cap were precasted in concrete as a whole, considered as a rigid system. The modulus of elasticity is $E=3.08 \times 10^{4} \mathrm{MPa}$. The cap had a dimension of $700 \mathrm{~mm} \times 700 \mathrm{~mm} \times 150 \mathrm{~mm}$ (length $\times$ width $\times$ thickness). As shown in Figures 1(a) and 2(b), strain gauges were stuck on the steel bars in reinforced concrete piles for the purpose of collecting the strain data during the tests, so that the axial force and negative skin friction could be calculated. Compared to arranging the strain gauges on the surface along the piles, placing the gauges on the steel bars inside the piles could better protect them from being damaged as well as influenced by the surrounding soil.

2.3. Soil Properties. The foundation soil was sand with a maximum and minimum dry density of 1.64 and $1.17 \mathrm{~g} / \mathrm{cm}^{3}$, respectively. The pile tips were settled on the top of the compacted backfill sand layer with the thickness of $300 \mathrm{~mm}$ counted from the base of the test chamber. The thickness of the surrounding soil was $1400 \mathrm{~mm}$. The basic physical properties of the sand are presented in Table 1.

2.4. Testing Process. The working load grades needed determining for studying the bearing capacity behavior in the water level rising and lowering cycle under different pile head loads. Based on the ultimate pile bearing capacity estimated according to the Chinese Technical Code for Building Pile Foundations [23], the pile head loads were determined to be $12 \mathrm{kN}$ and $24 \mathrm{kN}$, respectively, considering the experiment demand and laboratory conditions. It is noted that, in each condition, only one water level rising and lowering cycle was taken. Step-loading was adopted to ensure the test load being applied on the model piles slowly and stably. It was observed that the settlement of piles turned stable in 5 minutes, so the model piles were step-loaded every 5 minutes to the total loads via the servo hydraulic actuator, which reduced the sudden settlement of piles and the error of the measure elements during the loading process. After the variation of pile head displacement along with other data reaching stable, to simulate groundwater rising, water was injected through the PVC pipe with a diameter of $250 \mathrm{~mm}$ vertically placed at the corner of the test chamber. As shown in Figure 3, injection lasted 4 hours till the surface layer submerged, for the purpose of turning the dry sands saturated gradually. Then, the inject valve was turned off. The water was maintained at this level for 3 hours before 


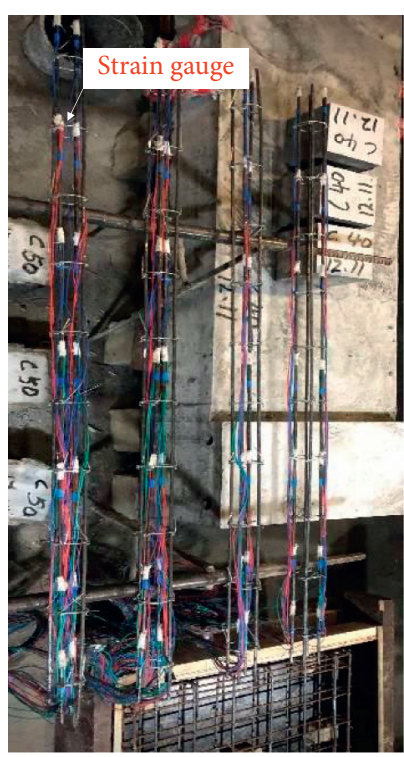

(a)

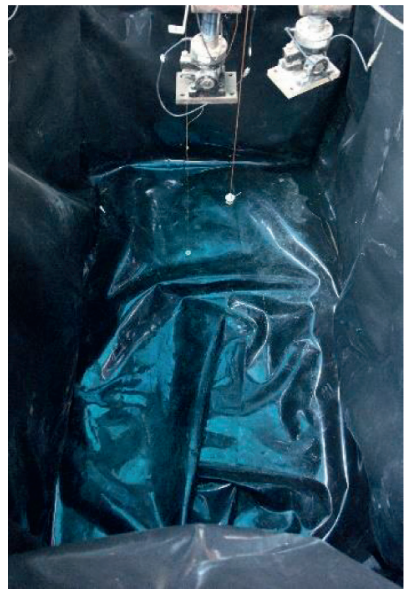

(d)

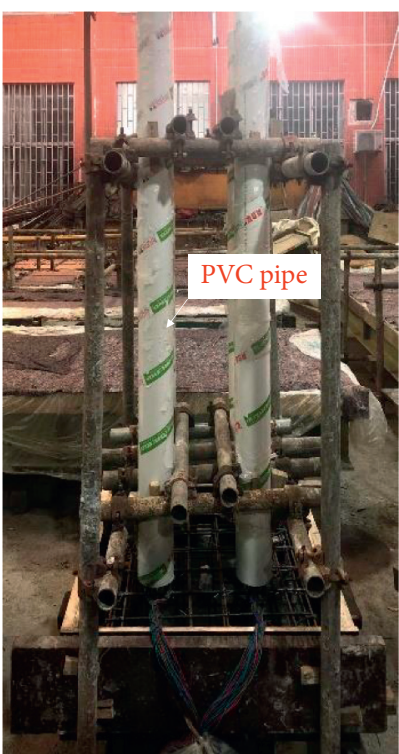

(b)

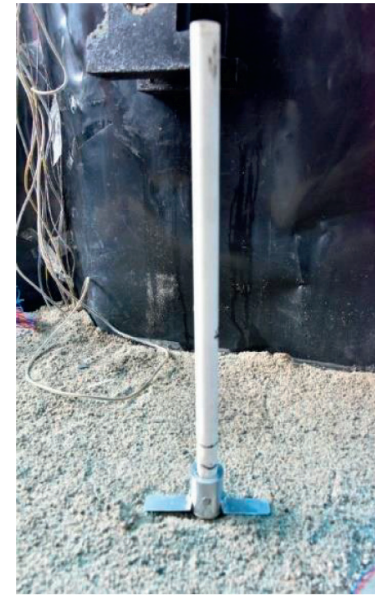

(e)

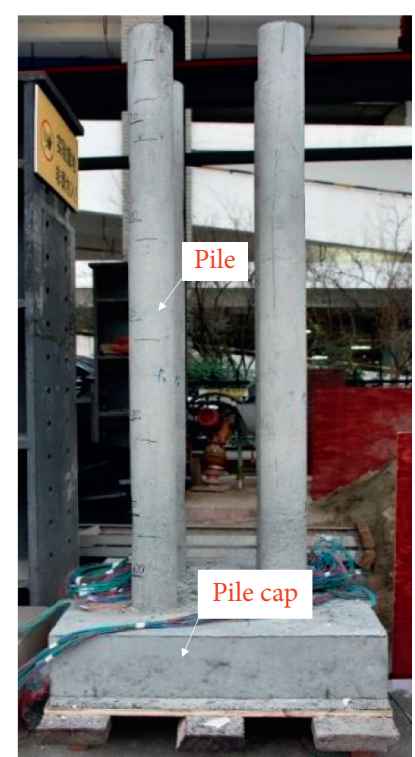

(c)

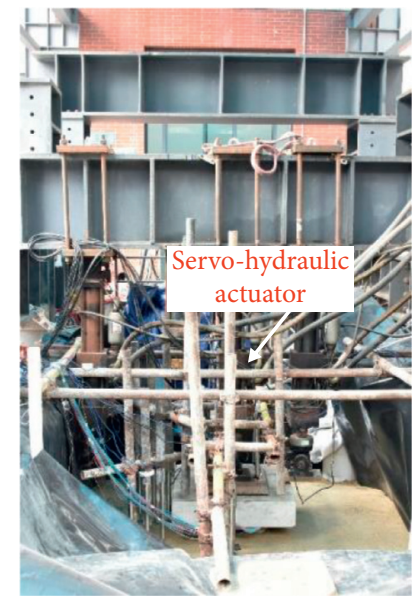

(f)

Figure 1: Test sites of model experiments. (a) Arrangement of strain gauges. (b) Casting test piles. (c) Test group piles. (d) HDPE geomembrane. (e) Layered settlement instrument. (f) Loading system.

being drained from the same pipe for 5 hours. During the experiment, the water level was measured every half an hour for determining and adjusting the speed of injection and drainage. After all water was drained from the test chamber, the pile heads were step-unloaded similarly as in the loading process.

\section{Results and Discussion}

3.1. Pile Bearing Capacity. Based on the technical code for inspection of building foundation piles [24], a maintained static loading test to failure was taken to determine the pile bearing capacity in the model test. The pile load settlement curve is shown in Figure 4. It could be surely observed that the ultimate total bearing resistance was $40 \mathrm{kN}$, with the ultimate pile head displacement of $1.54 \mathrm{~mm}$, as in approximately $0.015 D$ (pile diameter). The curve is in accordance with the hyperbolic model proposed by Seed and Reese [25], given by the following equation, to describe the interrelation between shaft (or pile tip) resistances and the relative displacement of the pile and soil.

$$
\tau(z)=\frac{S(z)}{a_{s}+b_{s}(z)} .
$$

$\tau(z)$ is the shaft resistance, $S(z)$ is the displacement of pile, and $a_{s}$ and $b_{s}$ refer to the factor of load mobilization of soil around piles.

3.2. Axial Force Distribution. The average axial force distribution of this $2 \times 2$ pile group was calculated based on the measured strain data. Figure 5 shows the average axial force distribution of this $2 \times 2$ pile group, and Figure 6 gives the typical result, meaning the axial force distribution of one pile in the pile group. It is noted that the load was applied on the 


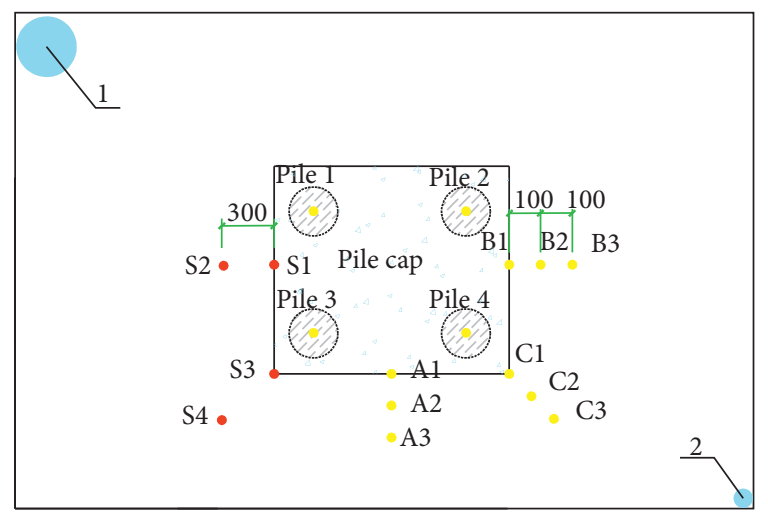

1 Water injection/ drainage pipe - Layered settlement marks 2 Water level measuring pipe - Vertical displacement gauges

(a)

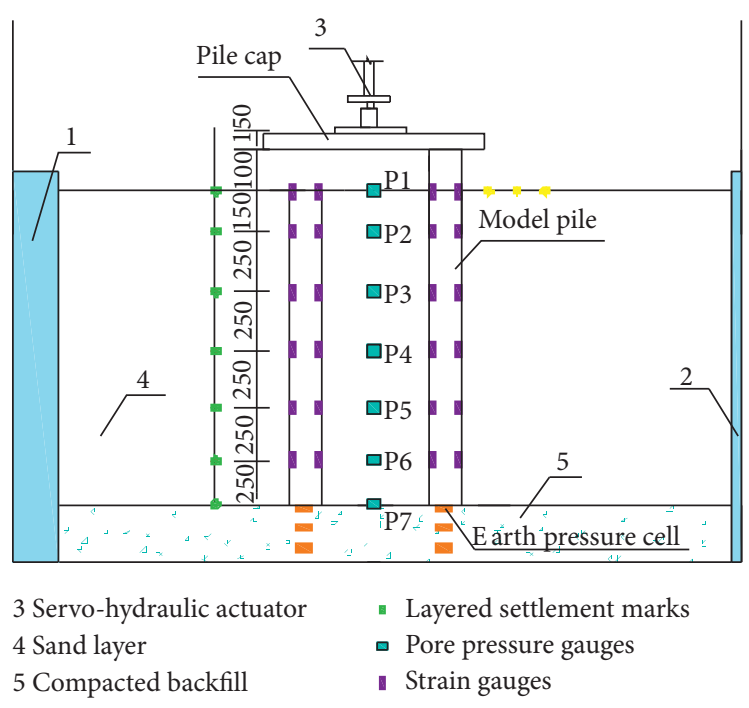

(b)

Figure 2: Layout of model test. (a) Plan view. (b) Longitudinal sectional view.

TABle 1: Parameters of soil for the test.

\begin{tabular}{lccccccccccc}
\hline Item & $\mathrm{Gs}$ & $\rho$ & $\rho \mathrm{d}$ & $\rho^{\prime}$ & $\mathrm{w}$ & $\varphi$ & $\mathrm{D} 10$ & $\mathrm{D} 30$ & $\mathrm{D} 60$ & $\mathrm{Cc}$ & $\mathrm{Cu}$ \\
\hline Value & 2.67 & 1.1291 & 1.0776 & 0.8145 & 4.633 & 31.1 & 0.605 & 0.26 & 1.13 & 1.1 & 4.35 \\
Unit & & $\mathrm{g} / \mathrm{cm}^{3}$ & $\mathrm{~g} / \mathrm{cm}^{3}$ & $\mathrm{~g} / \mathrm{cm}^{3}$ & $\%$ & & $\mathrm{~mm}$ & $\mathrm{~mm}$ & $\mathrm{~mm}$ & & \\
\hline
\end{tabular}

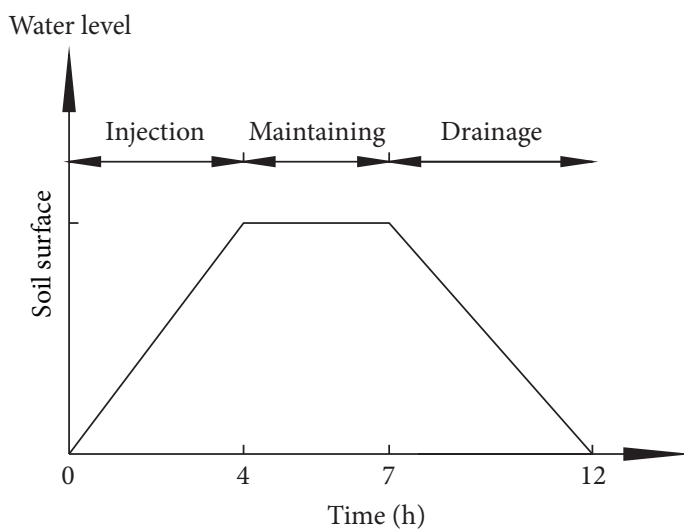

FIGURE 3: Schedule chart.

cap center in the whole test, and the period before water injection was named the loading phase.

Obviously, larger axial force under the load of $24 \mathrm{kN}$ occurs, and the value approximately doubled when compared to the $12 \mathrm{kN}$ condition. It could be also observed that the maximum axial force varied from about $7.6 \mathrm{kN}$ to $9.6 \mathrm{kN}$ under $12 \mathrm{kN}$ condition in water level rising and lowering cycle, and in the circle under $24 \mathrm{kN}$ condition, it ranged from $7.6 \mathrm{kN}$ to almost $9.6 \mathrm{kN}$, in which both featured almost the same maximum axial force fluctuation at about $2 \mathrm{kN}$ in each water level rising and lowering cycle. It suggested that the axial force varying caused by water level changing cycle was of little interference by the grade of pile head load. The axial force curves can be divided into two types by the form of trends among the four stages in the whole water level changing cycle. In the stage before the water level rose (namely, loading phase), which can be considered as ordinary loading tests with graded load levels of $12 \mathrm{kN}$ and $24 \mathrm{kN}$, the pile top featured the maximum axial force, witnessing a linear decrease to the minimum data occurring at the bottom along the pile in depth. It was in accordance with the traditional pile-soil interaction theory that part of the load carried by the pile could be transferred into the side soil and referred to the positive shaft resistance all along the pile. After water was involved, the axial force gradually enlarged and peaked at the middle of the pile, yet it showed a 


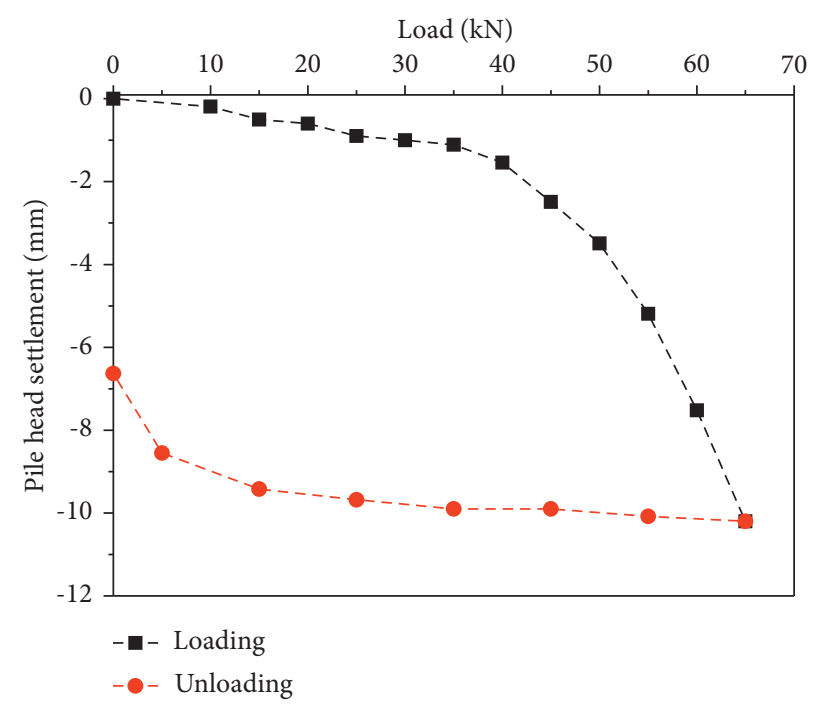

Figure 4: Pile load settlement curve.

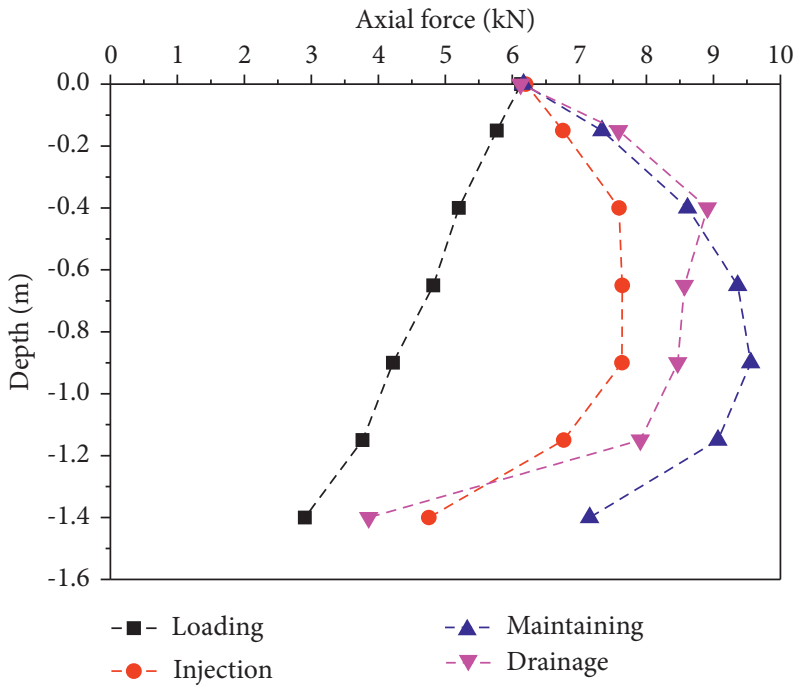

(a)

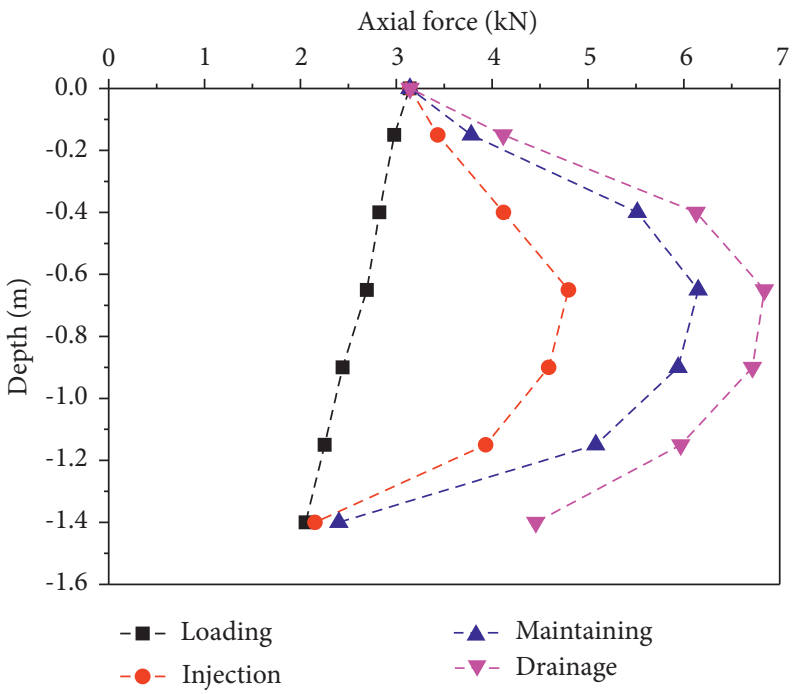

(b)

Figure 5: Average axial force distribution of piles in different test conditions. (a) Pile load: $12 \mathrm{kN}$. (b) Pile load: $24 \mathrm{kN}$.

reduced trend along the lower part of the pile similarly as the period before the water injection stage. This entailed the down drag force to the pile upper portion, factoring down the positive skin friction, leading to the amplified axial force. It can be viewed from Figure 5 that water changed the trend of the axial force distribution curve. The axial force values presented a gradually much increased trend with time after the water involved in, especially, injection and maintaining stage and the drainage phase (meaning water level lowering stage) experienced the largest axial force along the pile upper portion at about $0 \mathrm{~m}$ to $0.4 \mathrm{~m}$. It could be inferred that the water level changing (both rising and lowering) unfavorably enlarged the axial force, especially that of the upper part of the pile, furthermore, leading to weaken the bearing capacity of the pile foundation.
3.3. Negative Skin Friction Distribution. In order to analyze the down drag force more specifically, the average negative skin friction distribution and the typical data are presented in Figures 7 and 8, respectively, and it should be noted that the typical result means the negative skin friction distribution of one pile in the pile group. The negative friction resistance can be calculated according to the balance principle of force balance, and it is considered as a negative friction resistance downward; otherwise, it is a positive friction resistance. It could be observed that the shaft resistance was positive and existed along the pile skin at a grossly lower value in the loading phase, which implied that no negative friction resistance occurred as only the pile head load existed. However, after the water was injected, it was demonstrated clearly that the negative skin friction generated and developed as the experiment carried on, which was 


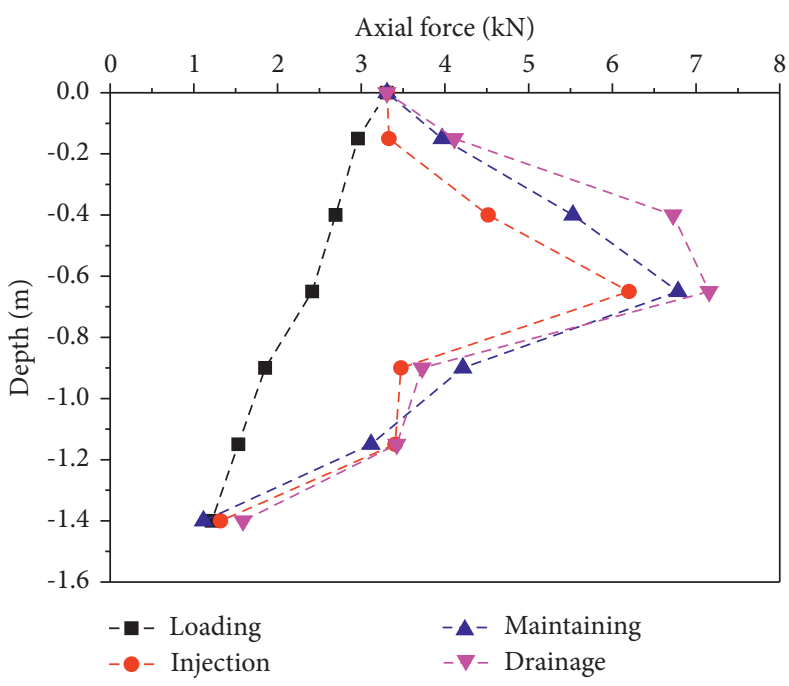

(a)

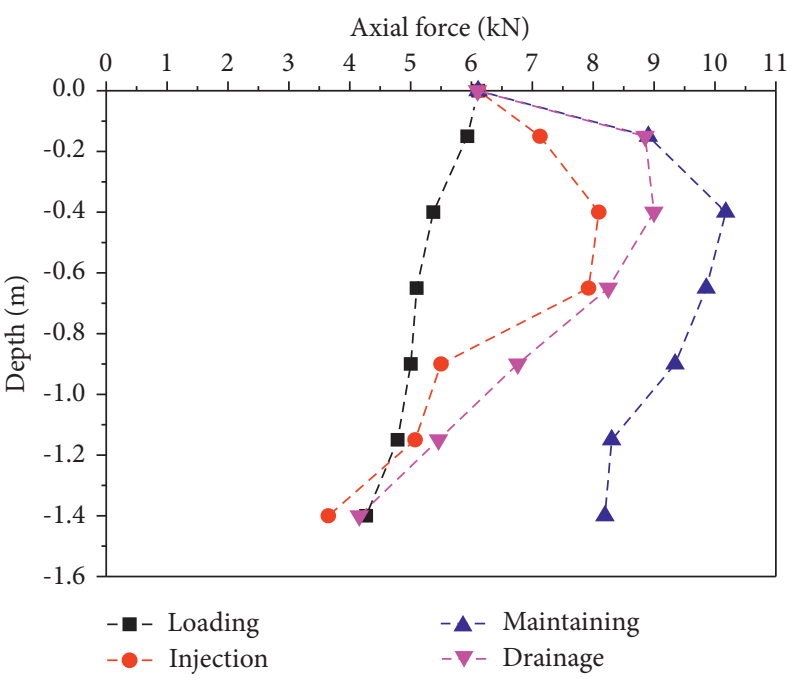

(b)

Figure 6: Typical axial force distribution of piles in different test conditions. (a) Pile load: $12 \mathrm{kN}$. (b) Pile load: $24 \mathrm{kN}$.

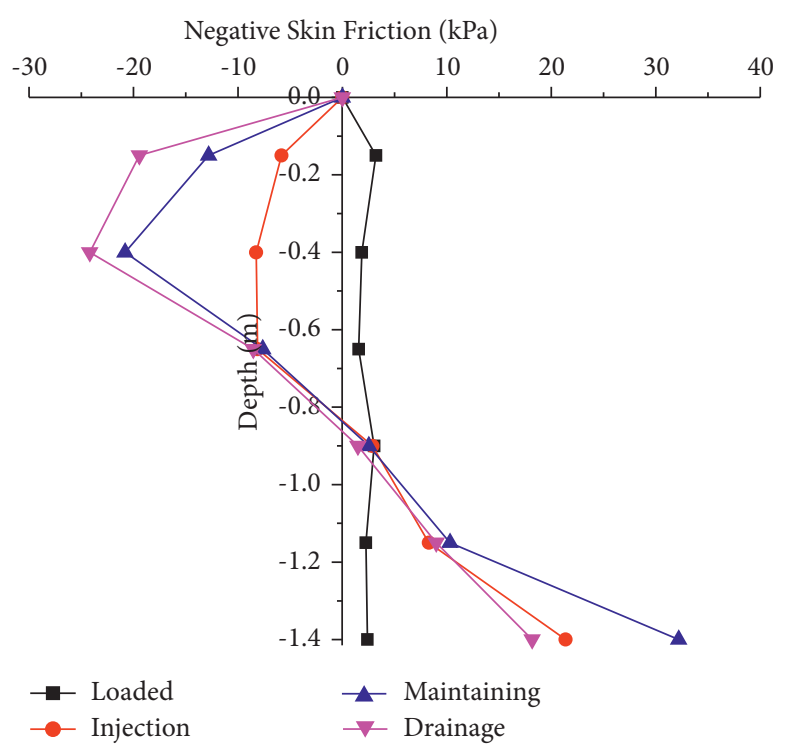

(a)

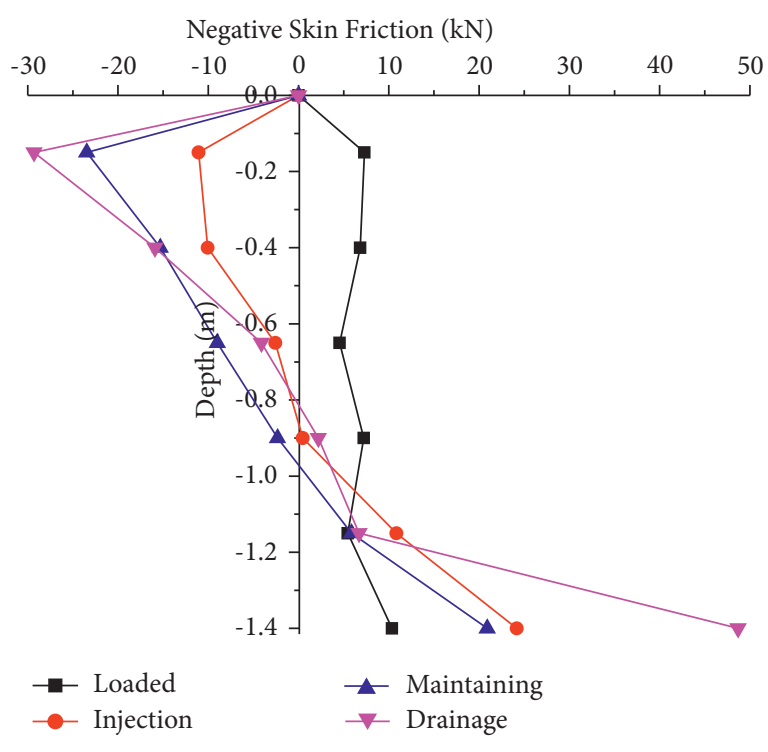

(b)

Figure 7: Average negative skin force distribution of piles in different test conditions. (a) Pile load: $12 \mathrm{kN}$. (b) Pile load: $24 \mathrm{kN}$.

corresponding to the regulation of the axial force curves and confirmed that it was unfavorable to the pile bearing capacity.

Sand particles maintained a balanced state of stress equilibrium in the loading phase. Water injection broke up the balance and rearranged the sand particles as well as the pores between them, which led to the induced effective stress and transformation from unsaturated to saturated state of the particles, thus, affecting the shaft resistance of pile. As the water level was constantly rising, the sand particles around the pile settled downward, and the negative skin friction generated and increased. In the stage of water level maintaining, the negative skin friction still climbed up, which implied that the stress state of sand particles still changed and did not reach stability and equilibrium. During the period of water level lowering, the negative skin friction enlarged further, because the drainage forced the saturated sand particles to turn into an unsaturated state, leading to an another increase of effective stress, and such conversion of stress status might well cause a downward movement of sands, which ensured another evident settlement of sand layers and enlarged displacement difference between soil and pile, resulting in more distinct negative skin friction, as clearly presented in the figures below. It can be also observed that the average negative skin friction increased when the pile head load changed from $12 \mathrm{kN}$ to $24 \mathrm{kN}$, suggesting that 


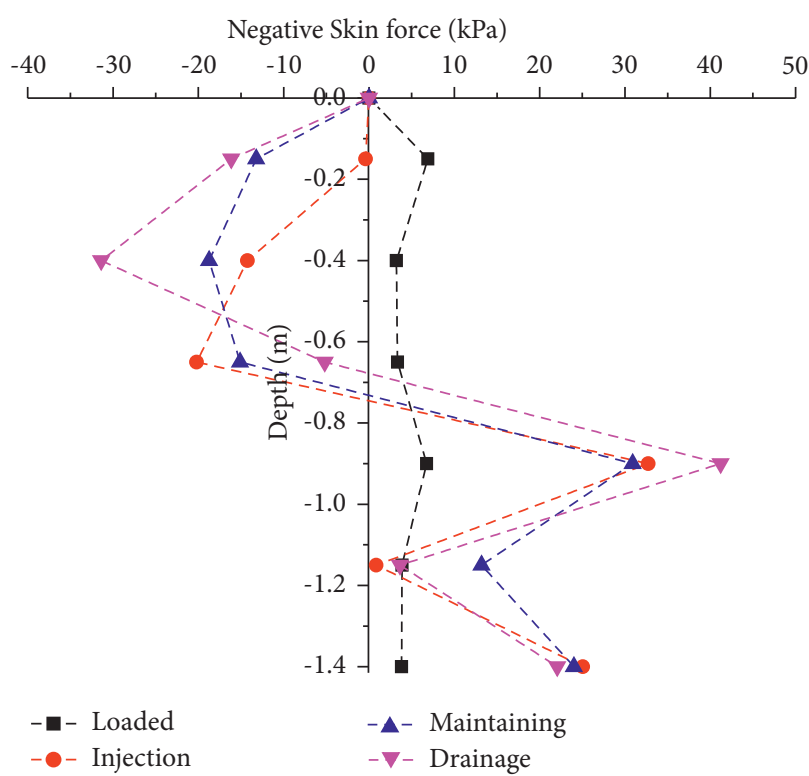

(a)

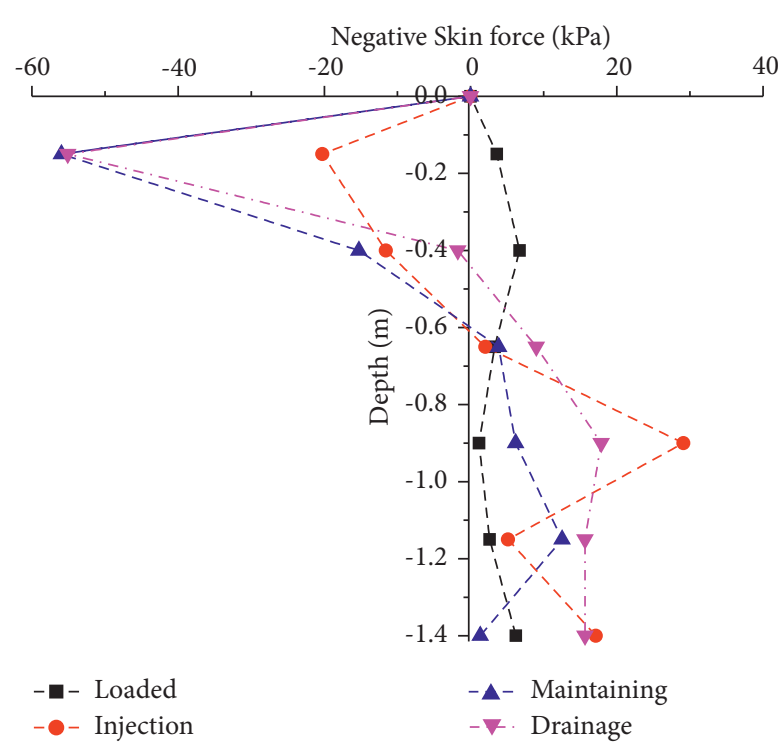

(b)

Figure 8: Typical negative skin force distribution of piles in different test conditions. (a) Pile load: $12 \mathrm{kN}$. (b) Pile load: $24 \mathrm{kN}$.

the value of negative skin friction was related to that of the pile head load. The neutral plane ranged from $0.8 \mathrm{~m}$ to $0.9 \mathrm{~m}$ ( $0.57 L \sim 0.64 L$, and $L$ represents the length of the pile.) from the pile head, which was in accordance with the previous study of the portion, where the neutral plane may well generate along the pile [26].

3.4. Pore Water Pressure. The arrangement of pore pressure gauges is illustrated in Figure 2(b). Each of the gauges was fixed on a $10 \mathrm{~cm}$ length iron wire for the convenience of placing pore pressure gauges in soil. Figure 9 shows the variation of pore water pressure with time. It can be observed obviously that the curve trend could be divided into three stages, which quite agrees with the water level variation trend. Besides, the value of pore water pressure was equal to the calculated hydrostatic pressure at measuring points. In the first four hours, the water was injected into the test chamber, filling up the pores between the sand particles, resulting in a rise of pore water pressure. During the maintaining stage, the water level was maintained, so the pore water pressure was observed to be stable. In the period of water level lowering, the water was gradually drained from the test chamber, so that the sand particles turned into unsaturated gradually, leading to the water in the pores between sand particles flowing away, resulting in the value of pore water pressure declining. The value of pore water pressure was grossly equal to the hydrostatic pressure, indicating no excess pore pressure generated in the whole process of water level changing cycle.

3.5. Settlement Analysis. Figure 10 shows the cap and pile head settlements. It could be viewed from the figure that the average settlement of the pile agreed well with that of the center of the cap, which confirmed the design intension mentioned in Section 2.2 that little deformation happened in the pile cap. The drag settlement during the water level rising period dominated for nearly $60 \%$ and $80 \%$ in the conditions of pile head load at $12 \mathrm{kN}$ and $24 \mathrm{kN}$, respectively, yet it still was maintained in the following saturated stage, with the total vertical displacement under $2.5 \mathrm{~mm}$.

The pile toe was on the compacted layer, and the soil of pile side ("sand layer" in Figure 2) was not compacted, featuring a looser structure. When changing the water level, particle rearrangement was more obvious in the surrounding soil than the compacted layer. The surrounding soil was observed to be a more distinct settlement compared to that of the pile, sorted as the surface soil settlement and the layered settlement. As illustrated in Figure 2, three measuring points spacing at $100 \mathrm{~mm}$ were arranged on the soil surface by the edge of the cap pile along each axis (axes A, B, and C). Average settlement was calculated separately sorting by the distance to the cap edge, and it is presented in Figure 11 (namely, legend 1 in Figure 11 represented the average value of measuring points $\mathrm{A} 1, \mathrm{~B} 1$, and $\mathrm{C} 1$, and legend 2 represented the average value of measuring points A2, B2, and C2, etc.) to evaluate horizontal distance various on soil settlement more specifically. It was shown that the sand near the cap edge witnessed more evident settlement, because the soil might well form a shearing band [27-29] to prevent the pile from settling down as the load applied on, and the soils closer to the cap edge tended to undertake more shear force, thus presenting more distinct settlement. A slight uplift was observed not far from the cap, which could be because of the forming trend of sliding surface as soil particles transferring shear stress, and once particles are squeezed out, it performed as the observed soil lifting on the surface. It shall also be noticed that the sand near the cap edge settled earlier, because it owned a shorter distance from the injection pipe, meaning getting soaked earlier. A more 


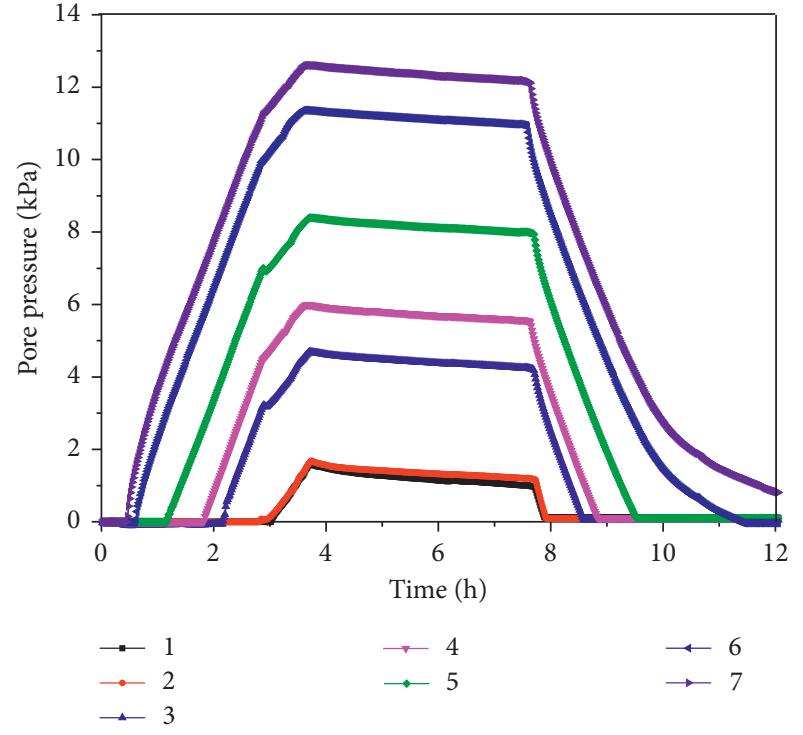

(a)

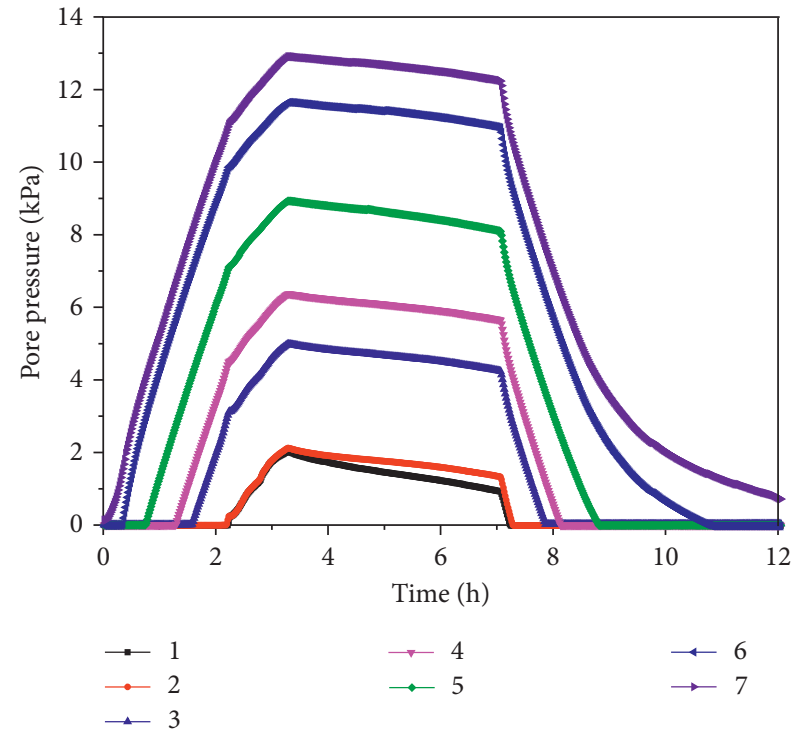

(b)

FIgURE 9: Variation of pore pressure with time. (a) Pile load: $12 \mathrm{kN}$. (b) Pile load: $24 \mathrm{kN}$.

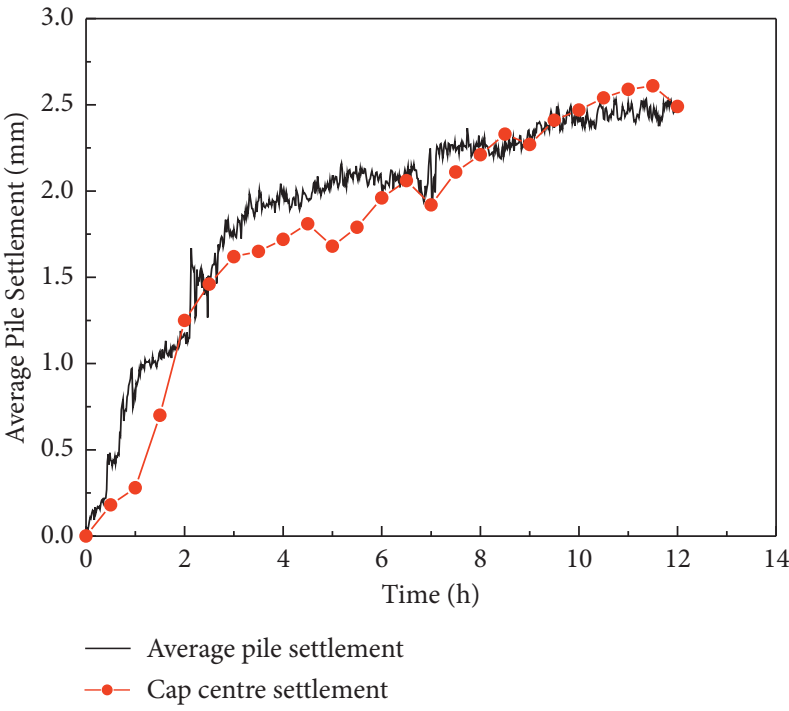

(a)

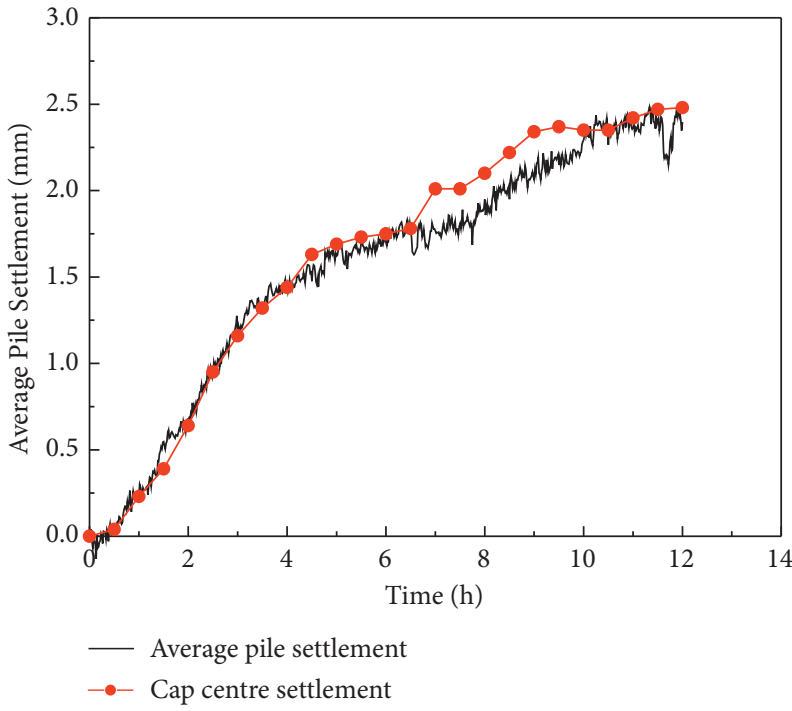

(b)

Figure 10: Cap center and pile settlement versus time. (a) Pile load: $12 \mathrm{kN}$. (b) Pile load: $24 \mathrm{kN}$.

obvious settlement occurred in the load of $12 \mathrm{kN}$ condition, because the sand was drier and structurally loose, compared to the pile head load of $24 \mathrm{kN}$ condition, leading to much larger interparticle pores and more distinct particle rearrangement in water injection. Settlement, however, slighter than the earlier water level rising period, also happened in the drainage stage, which referred to another particle rearrangement in this certain period, only with a gentler one, because the primary particle moving section had already been completed.
Layered settlement also confirmed the phenomenon that sand particles might well be settled in the water level lifting phase. Another regulation could be dug up was that the degree of settlement showed an accumulating trend, namely, diminished gradually as depth. Similar to the surface measuring points, the layered settlement was also marked as 1, 2, 3, and 4, as shown in Figure 2, and the results are demonstrated in Figure 12. Similarly, the soil presented more obvious layered settlement under $12 \mathrm{kN}$ load condition. Although some intersection points in $24 \mathrm{kN}$ load condition might not be so precise due to the 


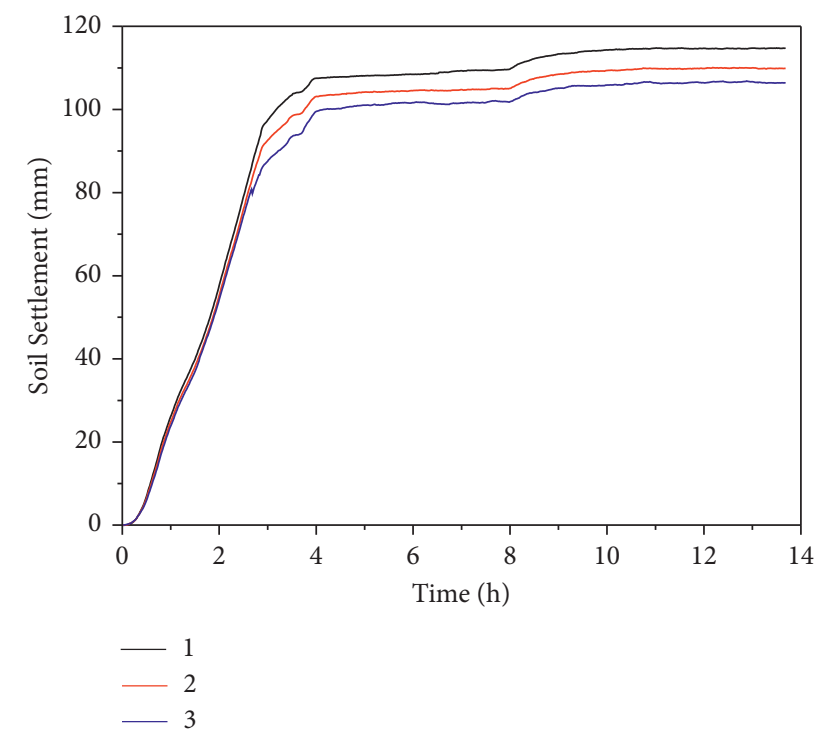

(a)

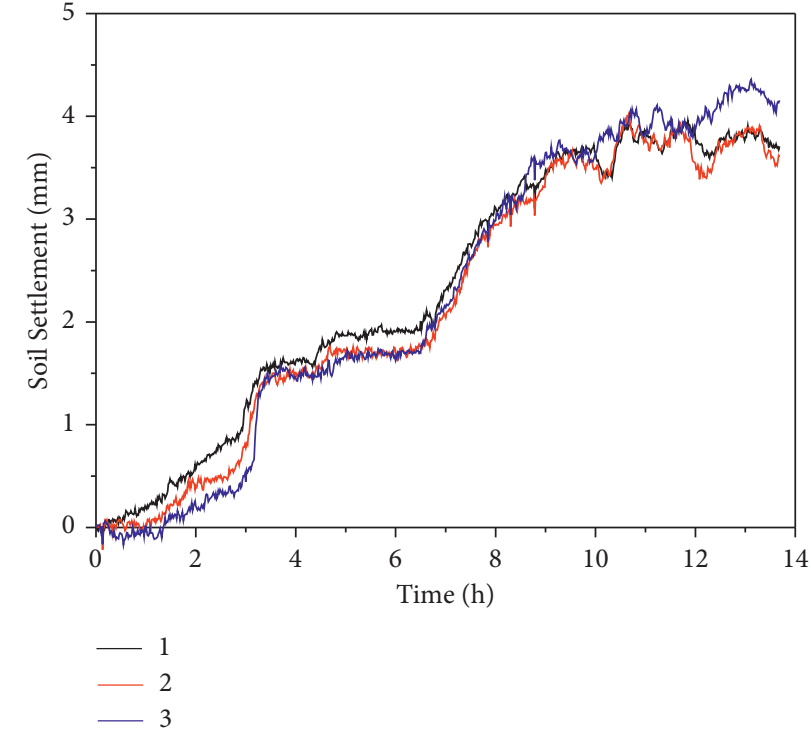

(b)

Figure 11: Average settlement of certain measure points of surface soil versus time. (a) Pile load: $12 \mathrm{kN}$. (b) Pile load: $24 \mathrm{kN}$.

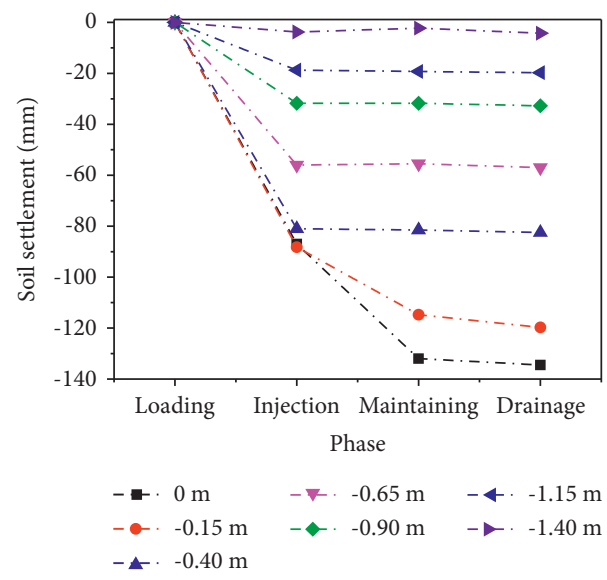

(a)

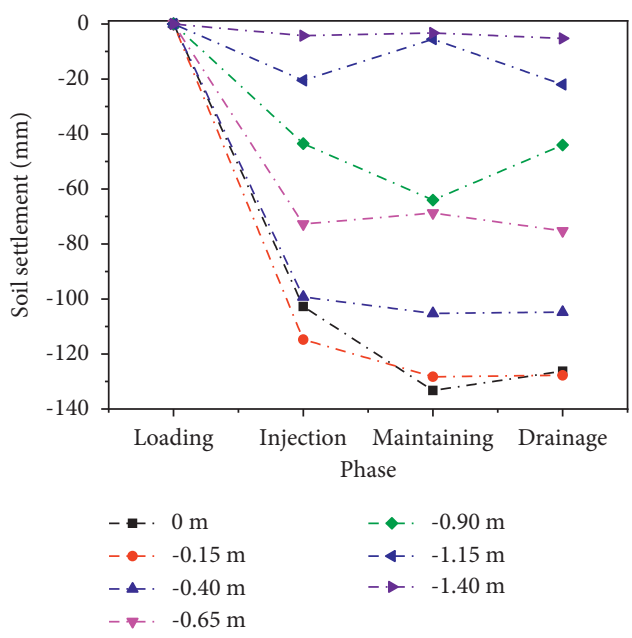

(c)

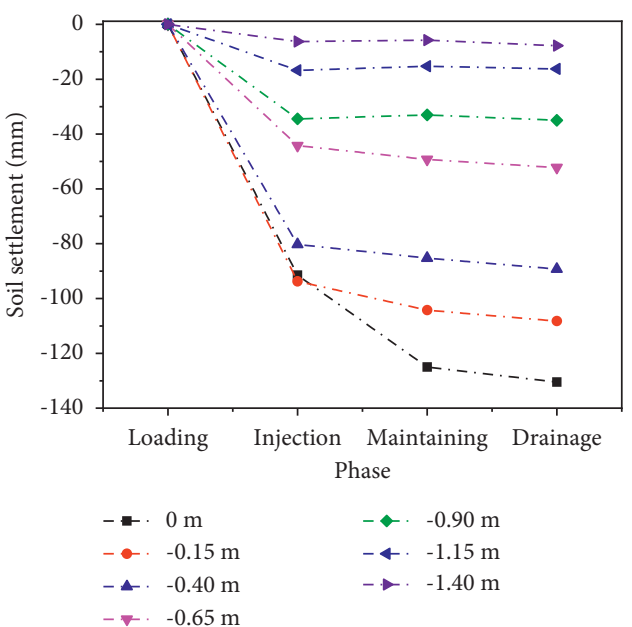

(b)

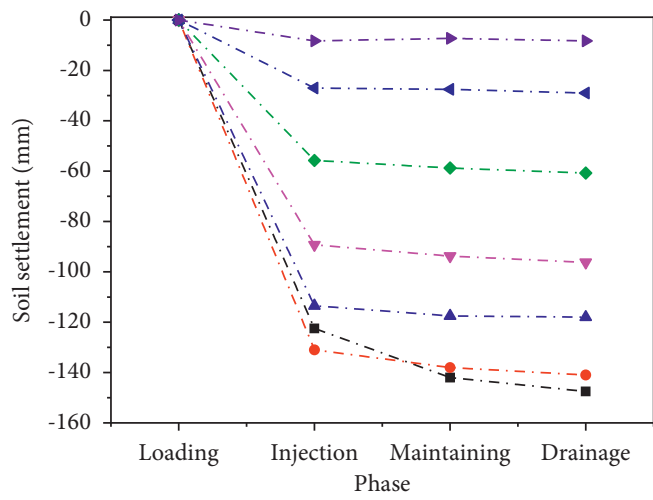

$$
\begin{aligned}
& \text { - } 0 \mathrm{~m} \\
& \text { - }-0.15 \mathrm{~m} \quad-4-1.15 \mathrm{~m} \\
& \text { - ^. }-0.40 \mathrm{~m} \\
& -\boldsymbol{\nabla} \cdot-0.65 \mathrm{~m}
\end{aligned}
$$

(d)

FIgURE 12: Continued. 


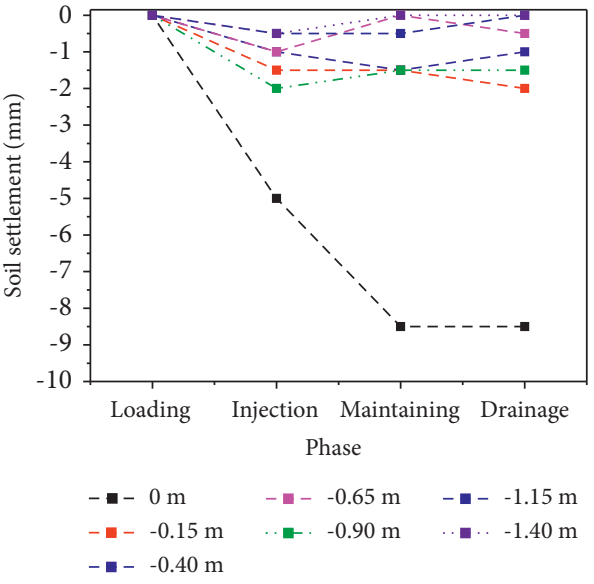

(e)

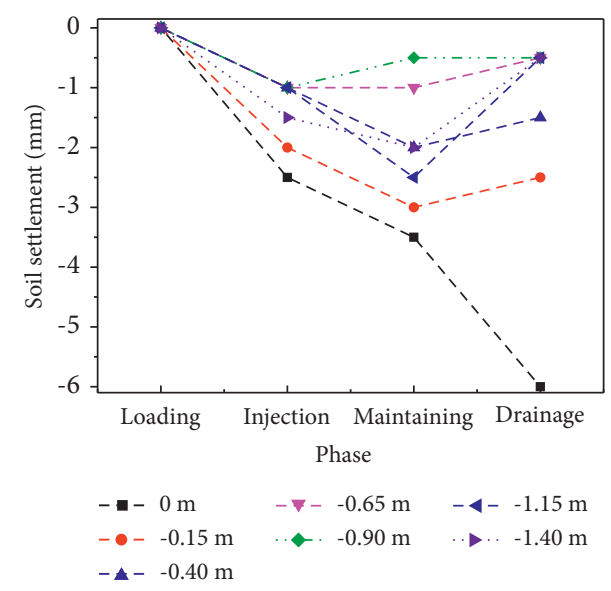

(g)

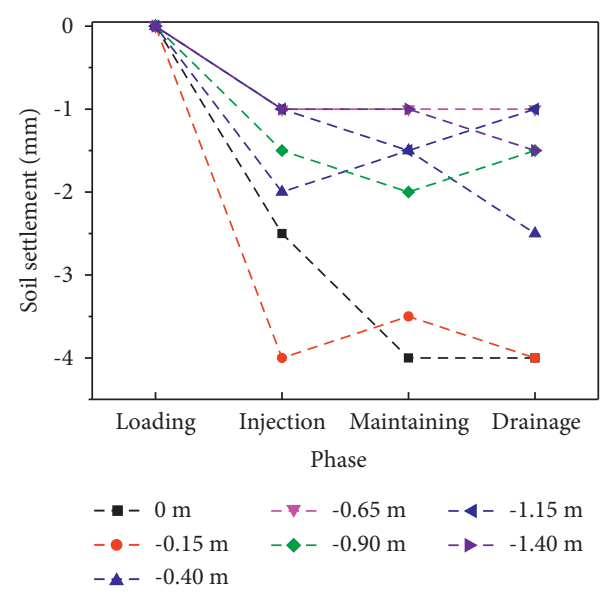

(f)

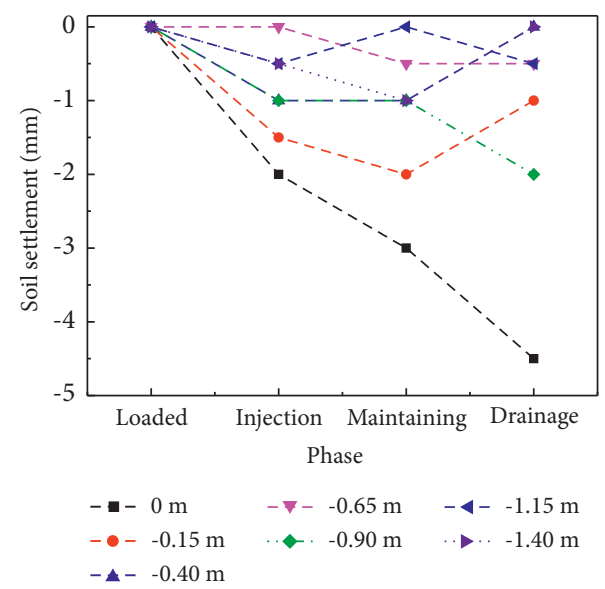

(h)

Figure 12: Settlement of layered soil versus time. (a) Point 1 (12 kN). (b) Point 2 (12 kN). (c) Point 3 (12 kN). (d) Point 4 (12 kN). (e) Point 1 $(24 \mathrm{kN})$. (f) Point $2(24 \mathrm{kN})$. (g) Point $3(24 \mathrm{kN})$. (h) Point $4(24 \mathrm{kN})$.

accuracy of mm degree, it could be still easily concluded that the soil of the surface layer featured the largest vertical displacement, while the bottom soil could hardly move in the whole cycle.

\section{Conclusions}

The bearing characteristic, especially negative skin friction, of the $2 \times 2$ pile group under water level rising and lowering condition is discussed in this paper, and the following conclusions are inferred:

(1) The water level rising and lowering cycle could increase the axial force of pile along the upper part of the pile, and the axial force peaked at the middle part, yet it reduced along the lower part of the pile. Although the absolute values of axial force ranged different under different grades of pile head load, it featured almost the same maximum axial force fluctuation at about $2 \mathrm{kN}$ in each cycle, which indicated that the vibration range of axial force caused by the water level rising and lowering cycle was hardly interfered by the grade of pile head load. The axial force changing caused by the water level rising and lowering cycle presented a feature of time effect, resulting in the maximum value of axial force occurring in the water level lowering stage.

(2) Negative skin friction caused by the water level rising and lowering cycle presented a feature of time effect, resulting in the maximum value of axial force occurring in the water level lowering stage. The average negative skin friction increased when the pile head load changed from $12 \mathrm{kN}$ to $24 \mathrm{kN}$, suggesting the value of negative skin friction was related to that of the pile head load. In addition, the neutral plane ranged from $0.57 L$ to $0.64 L$ as the water level changed.

(3) Soil settled when the water level rose and lowered and presented a feature of settling in layers, which suggested that the sand on the surface experienced a 
more evident settlement compared to the deeper sands down the layers. More distinct settlement of soil was observed in the water level rising stage, because the soil featured a loose structure and arrangement in this state, leading to larger pore spaces to be filled up by particles when water injected in.

(4) The change of pore water pressure was in accordance with the water level changing regulation either in variation trend or in value. The value of pore water pressure was equal to the hydrostatic pressure, indicating that no excess pore pressure was generated in the whole process of water level changing cycle.

\section{Data Availability}

The data used to support the findings of this study are available from the corresponding author upon request.

\section{Conflicts of Interest}

The authors declare that there are no conflicts of interest regarding the publication of this paper.

\section{Acknowledgments}

This work was supported by the Innovation Group Science Foundation of the Natural Science Foundation of Chongqing, China (Grant no. cstc2020jcyj-cxttX0003); POWERCHINA Huadong Engineering Corporation Limited (Grant no. KY2018-KC-06); and the Fundamental Research Funds for the Central Universities (Grant no. 2121CDJQY-042). The authors are grateful for their support.

\section{References}

[1] M. T. Davisson, "Negative skin friction in piles and design decision," in Proceeding of the 3rd International Conference Case Histories Geotechnical Engineering, pp. 1793-1811, Missouri, June 1993.

[2] Y. B. Acar, R. Avent, and M. R. Tara, "Down drag on friction piles: a case history," Proceeding of the Settlement 94: Vertical and Horizontal Deformations of Foundations and Embankment, Geotechnical Special Publication, vol. 2, no. 40, pp. 986-999, 1994.

[3] H. G. Polous, "Piles subjected to negative friction: a procedure for design," Geotechnical Engineering, vol. 28, no. 1, pp. 23-44, 1997.

[4] M. Thomas, M. Fahey, and R. J. Jewell, "Pile downdrag due to surface loading," Proceedings of the International Conference Centrifuge, vol. 98, no. 1, pp. 507-512, 1998.

[5] L. Luan, X. Ding, C. Zheng, G. Kouretzis, and Q. Wu, "Dynamic response of pile groups subjected to horizontal loads," Canadian Geotechnical Journal, vol. 57, no. 4, pp. 469-481, 2020.

[6] L. Luan, C. Zheng, G. P. Kouretzis, and X. Ding, "Dynamic analysis of pile groups subjected to horizontal loads considering coupled pile-to-pile interaction," Computers and Geotechnics, vol. 117, Article ID 103276, 2020.

[7] C. Cui, K. Meng, C. Xu, Z. Liang, H. Li, and H. Pei, “Analytical solution for longitudinal vibration of a floating pile in saturated porous media based on a fictitious saturated soil pile model," Computers and Geotechnics, vol. 131, Article ID 103942, 2021.

[8] X. Ding, L. Qu, J. Yang, and C. Wang, "Experimental study on the pile group-soil vibration induced by railway traffic under the inclined bedrock condition," Acta Geotechnica, vol. 15, no. 12, pp. 3613-3620, 2020.

[9] K. Meng, C. Cui, Z. Liang, and H. Li, "A new approach for longitudinal vibration of a large-diameter floating pipe pile in visco-elastic soil considering the three-dimensional wave effects," Computers and Geotechnics, vol. 128, Article ID 103840, 2020.

[10] K. S. Wong and C. I. Teh, "Negative skin friction on piles in layered soil deposits," Journal of Geotechnical Engineering, vol. 121, no. 6, pp. 457-465, 1995.

[11] C. J. Lee, J. H. Jeong, and J. C. Lee, "The influence of soil slip on negative skin friction in pile groups connected to a cap," Géotechnique, vol. 56, no. 1, pp. 53-56, 2006.

[12] G. Kong, Q. Yang, and M. Luan, "Loading sequence effects on dragload and downdrag for pile foundation," Transactions of Tianjin University, vol. 16, no. 3, pp. 203-208, 2010.

[13] Y. Hong, C. W. W. Ng, and Y. Chen, "Field study of downdrag and dragload of bored piles in consolidating ground. journal of performance of constructed facilities," Journal of Performance of Constructed Facilities, vol. 30, no. 3, pp. 1-11, 2015.

[14] S. A. Tan and B. H. Fellenius, "Negative skin friction pile concepts with soil-structure interaction," Geotechnical Research, vol. 3, no. 4, pp. 1-11, 2016.

[15] J. C. Lee and C. R. Chen, "Negative skin friction on piles due to lowering of groundwater level," Journal of the Southeast Asian Geotechnical Society, vol. 34, pp. 13-25, 2003.

[16] A. Fahmi, J. Dabbagh, and M. Moezzi, "FE Analysis and experimental validation of land subsidence due to ground water level variation," International Journal of Engineering \& Technology, vol. 4, no. 3, pp. 451-459, 2015.

[17] L. Fu, Study on the Effect of Ground Water Level Variation on the High Speed Railway Viaduct Foundations, Master thesis, Zhejiang University, Zhejiang, China, 2019.

[18] R. R. Al-Omari, M. Y. Fattah, and S. H. Fadhil, "Load sharing and behavior of single pile embedded in unsaturated swelling soil," European Journal of Environmental and Civil Engineering, vol. 24, no. 12, pp. 1967-1992, 2020.

[19] R. R. Al-Omari, M. Y. Fattah, and A. M. Kallawi, "Laboratory study on load carrying capacity of pile group in unsaturated clay," Arabian Journal for Science and Engineering, vol. 44, no. 5, pp. 4613-4627, 2018.

[20] M. Y. Fattah, B. S. Zabar, and F. S. Mustafa, "Effect of saturation on response of a single pile embedded in saturated sandy soil to vertical vibration," European Journal of Environmental and Civil Engineering, vol. 24, no. 3, pp. 381-400, 2017.

[21] R. R. Al-Omari, M. Y. Fattah, and S. H. Fadhil, "Adhesion factor of piles embedded in unsaturated swelling soil," in Proceedings of the 19th International Conference on Soil Mechanics and Geotechnical Engineering, pp. 2703-2706, Seoul, South Korea, September 2017.

[22] M. Y. Fattah and F. S. Mustafa, "Development of excess pore water pressure around piles excited by pure vertical vibration," International Journal of Civil Engineering, vol. 15, no. 6, pp. 907-920, 2016.

[23] Ministy of Construction of the People's Republic of China, Technical Code for Building Pile Foundations, Design code, China building industru press, China, Sichuan, 2014.

[24] Ministry of Housing and Urban-Rural Development of the People's Republic of China, Technical Code for Testing of 
Building Foundation Piles, Design code, China building industry press, China, Sichuan, 2014.

[25] H. B. Seed and L. C. Reese, "The action of soft clay along friction piles," Transactions of the American Society of Civil Engineers, vol. 122, pp. 731-754, 1955.

[26] M. S. Lu, "Experimental study and empirical formula of negative friction resistance on pile foundation surface," Port and waterway engineering, vol. 5, pp. 54-58, 1997.

[27] L. Li, W. Wu, H. Liu, and B. Lehane, "DEM analysis of the plugging effect of open-ended pile during the installation process," Ocean Engineering, vol. 220, no. 4, Article ID 108375, 2020.

[28] Y. Peng, X. Ding, Y. Xiao, X. Deng, and W. Deng, "Detailed amount of particle breakage in nonuniformly graded sands under one-dimensional compression," Canadian Geotechnical Journal, vol. 57, no. 8, pp. 1239-1246, 2020.

[29] Y. Peng, H. Liu, C. Li, X. Ding, X. Deng, and C. Wang, "The detailed particle breakage around the pile in coral sand," Acta Geotechnica, vol. 16, no. 6, pp. 1971-1981, 2021. 